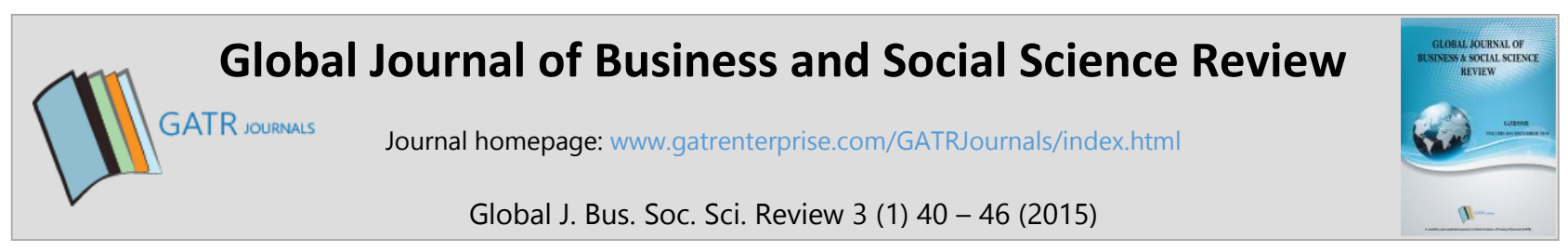

\title{
Diffusion of Innovations on E-Customs Business to Government IT: Developing E-Government Services New Concepts and Technologies
}

\author{
Maria Mia Kristanti* \\ Widya Mandala Catholic University,Dinoyo 42-44,60256,Surabaya, Indonesia
}

\begin{abstract}
Objective - This research aims to investigate how e-customs innovation diffusion may take place focusing on the benefits that it can bring to potential stakeholders, for business companies and governments. Two research models have been developed based on a literature review on diffusion of IT innovations as well as on value assessment methods used for IT innovations implemented in the private and public sector. The first part of research aims to illustrate the innovationdevelopment of business-to government IT innovations, while the second aims to provide a guideline on important variables needed to conduct value assessment for such innovations as well as how to classify the identified benefits.

Methodology/Technique - Multiple SEM analysis on e-customs has been carried out in order to test the proposed research models involving different business companies and governmental bodies.

Findings - The research model were based on valid and in-depth relevant theoretical analysis.

Novelty - This conceptual research is an evidence of continuous improvement building in an struggling effort from Indonesian government in reducing the poor living. The government have strong and dominant role as an agent of change to innovate the way of doing business for living. View of research studying this correlations in Indonesian context.

Type of Paper: Empirical
\end{abstract}

Keywords: Diffusion of Innovations, E-Customs, E-Government Services.

JEL Classification: G29, L81.

\section{Introduction}

Broader ICT access opens innovative territory for citizen participation, electoral support, educational development and service delivery, all of which are critical to governance development. As citizens are able to engage more easily and effectively with governing processes through new mobile and online tools, governments are recognizing the need to integrate ICT development into national development agendas (Accenture, 2014). e-governance initiatives also need to consider how governments can capitalize on connectivity to better serve citizen needs through innovations in e-administration, e-service delivery and eparticipation, and should look for ways of enhancing people's participation in policy decision-making and other governance processes (UN, 2008). Many new platforms have been developed which can broaden stakeholder engagement, and these ICT innovations can be harnessed to foster citizen participation.

\footnotetext{
* Paper Info: Received: December 13, 2014

Accepted: January 16, 2015

* Corresponding author:

E-mail: miagnews@gmail.com

Affiliation: Marketing Lecturer in Business Faculty of Widya Mandala Catholic University
} 
Cooperative partnerships with local municipalities, the private sector, financial institutions and other nontechnical partners can help target issues of sustainability and efficiency. Affordable Internet access, for example, is easier to sustain when partnerships and or alternative sources of funding are established during the early planning stages (Johnson, 2003). Indonesia has a population of more than 242 million, the largest of the countries studied. Its GDP per capita is $\$ 3,813$ and it ranks 124 th on the HDI, making it a 'medium human development' country according to the HDR (UN, 2010). Indonesia has a literacy rate of 92 percent. It ranks 100 on the GII of the HDR, placing it below the median internationally in terms of gender equity. It also has the second lowest life expectancy at 69.4 years. World Bank indicate that 13.3 percent of Indonesia's population lives below the poverty line, with 18.7 percent living on less than $\$ 1.25$ a day (UN, 2010). Indeed, Indonesia also has witnessed a rapid diffusion of new information and communication technologies. Over the past decade, the country has spent nearly a trillion dollars on information technology hardware, software and other services, and the government has created innovative programmes for ICTs in agriculture, education and health as well as women's access to information and microenterprise development. Indonesia's Networked Readiness Index ranking high (a composite of policy environment, readiness and usage) (UN, 2005). New government policies include a high-level strategic plan for ICTs from the Ministry of Communication and Information, a national ICT vision and a high-level ICT coordinating team (Accenture, 2014).

\section{Theoretical Background}

\section{1 e-Government Definition}

The World Bank (The World Bank Group, 2001) defines and describes the benefits of e-government as: The use by government agencies of information technologies (Networks, the Internet, and mobile computing) that have the ability to transform relations with citizens, businesses, and other arms of government. These technologies can serve a variety of different ends: better delivery of government services to citizens, improved interactions with business and industry, citizen empowerment through access to information, or more efficient government management. The resulting benefits can be less corruption, increased transparency, greater convenience, revenue growth, and/or cost reductions." This definition explains different uses and the benefits of e-Government. It also stresses that ICT, the internet and mobile computing are e-government tools. From these definitions it can be concluded that e-Government is a system that literally engages and covers every entity in its area of authority (i.e. citizens, businesses and public organisations). In other words, depending on the services offered, its scope includes everyone in its jurisdiction. In some instances, its scope can surpasses jurisdictional boundaries, where external services to people and businesses, such as tourism and foreign investment services, are provided. Bretschneider (2003) defines e-Government as "the use of information technology in general, and e-commerce in particular, to provide citizens and organizations with more convenient access to government information and services ..." This definition places ICT and e-commerce as vital components of e-Government and emphasises the close relationship between e-commerce and egovernment. The conclusion is that e-Government benefits extend to service providers as well as the target users. If e-Government is properly designed and developed, it provides all stakeholders with a winning situation, enabling savings in time, cost and effort.

\subsection{Advantages of e-Government}

The internet is ubiquitous. In the past, it was mainly used for educational and information sharing purposes (Norris and Moon, 2005), but internet applications now facilitate day-to-day activities. e-Government is an important application of the internet and is used by authorities to encourage broad use of computers and to facilitate communication and interactions with its institutions, citizens and businesses (Brown, 2005). Cutting red tape, enhancing the efficiency and effectiveness of the services offered and reducing costs for both users and the service providers are some of the aims and goals behind the adoption of this mode of service provision 
(Berry, 2006). Despite this, e-Government should not be thought of as the solution for such inefficiencies but rather the tool that increases the urgency for such aims and ambitions (Taylor and Todd, 2005).

\subsection{Service Innovation}

Major stakeholders tried to design, development, delivery and maintenance of e-Goverment services include managers (a role as leaders), domain experts (a role that knows more about domain knowledge), IT staff (staff responsible for IT), application service providers (ASPs, out-sourced private firms who execute an activity-specific service) and end users (receivers of an e-service) (West, 2005). Among these, ASPs belong in the category of knowledge-intensive business services (KIBS), whose roles in innovation processes have been studied extensively (Sundbo, 2008). Furthermore, it is possible for the various series of changes or innovations to take place in the various areas of technology (new techniques for making products or services), product (modifications of existing products or development of new product lines), administration (changes in organizational structures, goals, information and other systems) or people (changes in leadership abilities, or the capability to use new technology for delivering services) (Coursey and Norris, 2008). Lin (2003) proposes a four-dimensional framework new service concept, client interface, service delivery system/organisation and technological options, to analyse service innovation. The service concept dimension is an intangible conceptual element which is novel in its application to a particular market. The client interface dimension is the design of the interface between the service provider and its clients. The service delivery system dimension refers to the internal organisational arrangements that have to be managed to empower employees to perform their job properly. The technological options dimension, meanwhile, concerns the degree to which adopters themselves are in practice shaping technological development.

\subsection{Government e-Service Innovation}

IT investment could bring public service with new value (Hipp and Grupp, 2005). We use the construct of core/delivery benefit to define the value created by new customer interfaces in an e-government context. In cyberspace, online services create new opportunities that differ from traditional services (Bretschneider, 2003). That is to say, government agencies can innovate by offering an important new 'core benefit' or a new 'delivery benefit' that revolutionizes citizens' access to the core benefit. In other words, core benefit connotes providing new services to new users and delivery benefit involves taking existing service and providing it with new accessibility to existing users (Berry, 2006).

We believe that if emphasis is placed on what convenience e-Government services provide citizens and what kind of opportunities are thus created, these can be viewed in terms of a delivery benefit and of a core benefit (West, 2005). The delivery benefit refers to those operations that can be completed online, for instance filing taxes, the procedures for which include verification of identity, calculation of taxes payable (carried out automatically by the system), provision of a variety of methods for payment, and online transmission of this (Johnson, 2003). In this scenario, citizens can complete their tax-filing procedures without leaving home. Therefore, timely, ease of use, accuracy etc. are the criteria that must be followed (Gilding and Critchley, 2003). As for core benefit, this comes in the form of services citizens can obtain through access to the databases of various government agencies, which saves them having to visit a variety of offices to complete a single, multi-part task, and where the various steps can be taken through a single, integrated window, citizens or businesses alike are saved a great deal of effort (Joines et al, 2003). With this integrated service, the entire operation is accelerated and trade is made all the more convenient (Ross et al, 1996). 


\subsection{Hypotheses}

The theoretical confirmation between the all research variables, conclude eighteen hypotheses as follow:

1. There is positive correlation between Performance Expectancy and Marketing Strategy.

2. There is positive correlation between Effort Expectancy and Marketing Strategy.

3. There is positive correlation between Social Influences and Marketing Strategy.

4. There is positive correlation between Facilitating Conditions and Marketing Strategy.

5. There is positive correlation between Policy Issues and Marketing Strategy.

6. There is positive correlation between Human Capital Experiences and Marketing Strategy.

7. There is positive correlation between Partnership and Collaboration and Marketing Strategy.

8. There is positive correlation between Performance Expectancy and Leadership Value.

9. There is positive correlation between Effort Expectancy and Leadership Value.

10. There is positive correlation between Social Influences and Leadership Value.

11. There is positive correlation between Facilitating Conditions and Leadership Value.

12. There is positive correlation between Policy Issues and Leadership Value.

13. There is positive correlation between Human Capital Experiences and Leadership Value.

14. There is positive correlation between Partnership and Collaboration and Leadership Value.

15. There is positive correlation between Marketing Strategy and Service Innovation.

16. There is positive correlation between Leadership Value and Service Innovation.

17. There is positive correlation between Service Innovation and Service Value.

18. There is positive correlation between Service Value and Consumer Value for Living and Wealth.

\section{Methodology}

This study was conducted to analyze the inhibiting factors of e-Government in the province of Java. The target of the population was East Java province government employees. Data were collected using a survey method with one shot data collection in which the sampling was drawn by using purposive/judgment sampling. The sample size was determined using the conventional approach. According Hair et al (2006), structural equation modelling requires a sample size of between 100-200 respondents. A pre-test of 50 samples was conducted among the respondents to check reliability and validity of the questionnaire. This research aims to collect 350 qualified answers. We used questionnaires as a measuring instrument to the variables in the research model. The questionnaires were sent to 19 government agencies in the East Java province. The instrument used in this study was constructed by combining several previous research instruments. The questions in the questionnaires were designed based on the measurement items for each construct or latent variable models that exist in the design of the study. The questionnaire items are measured by a Likert's scale ranging from 1 to 5 (1="strongly disagree", $5=$ ="strongly agree").

\section{Results and Discussion}

The study findings reflected the following factor solutions and reliabilities with SPSS 17 as:

\subsection{Regression Analysis}

Linear regression analysis has been tested to analyse the effects of twelve variables of service innovation in e-government to changes on Indonesian society wealth. The major findings of regression analysis for each hypothesis of the research are: 
Table 1. Hypothesis Test of F ANNOVA

\begin{tabular}{|c|c|c|c|c|c|}
\hline Model & $\begin{array}{c}\text { Sum of } \\
\text { Squares }\end{array}$ & Df & $\begin{array}{c}\text { Mean } \\
\text { Square }\end{array}$ & F & Sig \\
\hline 1 & 85.97 & 70 & 1.070 & 1995.08 & 0.000 \\
Regression & 0.000 & 87 & 0.000 & & \\
Residual & 97.65 & 91 & & & \\
Total & & & & & \\
\hline
\end{tabular}

F-Value shows that the research models were fit with all the data. As F-Value of 1995.08 is greater than probability base value of $0.000 \leq 0.001$. It also means that, the research data were also qualified. The table 2 bellow shows the hypotheses results as:

Table 2. t- Table, Hypotheses Test

\begin{tabular}{|c|c|c|c|c|c|}
\hline Test & Variable & Estimate & $\begin{array}{c}\text { Critical } \\
\text { Ratio }\end{array}$ & t-table & Category \\
\hline $\mathrm{H}_{1}$ & PE-MS & 97.05 & 7.63 & 1.96 & Excepted \\
\hline $\mathrm{H}_{2}$ & EP-MS & 67.30 & 8.25 & 1.96 & Excepted \\
\hline $\mathrm{H}_{3}$ & SC-MS & 89.78 & 0.27 & 1.96 & Excepted \\
\hline $\mathrm{H}_{4}$ & FC-MS & 87.99 & 3.12 & 1.96 & Excepted \\
\hline $\mathrm{H}_{5}$ & PI-MS & 95.19 & 8.10 & 1.96 & Excepted \\
\hline $\mathrm{H}_{6}$ & HC-MS & 90.98 & 29.98 & 1.96 & Excepted \\
\hline $\mathrm{H}_{7}$ & PAC-MS & 76.80 & 10.19 & 1.96 & Excepted \\
\hline $\mathrm{H}_{8}$ & PE-LV & 82.96 & 5.17 & 1.96 & Excepted \\
\hline $\mathrm{H}_{9}$ & EF-LV & 93.01 & 8.63 & 1.96 & Excepted \\
\hline $\mathrm{H}_{10}$ & SC-LV & 87.80 & 8.98 & 1.96 & Excepted \\
\hline $\mathrm{H}_{11}$ & FC-LV & 70.98 & 9.27 & 1.96 & Excepted \\
\hline $\mathrm{H}_{12}$ & PI-LV & 56.96 & 6.58 & 1.96 & Excepted \\
\hline $\mathrm{H}_{13}$ & HC-LV & 94.54 & 7.50 & 1.96 & Excepted \\
\hline $\mathrm{H}_{14}$ & PAC-LV & 86.68 & 5.56 & 1.96 & Excepted \\
\hline $\mathrm{H}_{15}$ & MS-SI & 47.80 & $6, .9$ & 1.96 & Excepted \\
\hline $\mathrm{H}_{16}$ & LV-SI & 86.60 & $5 . .9$ & 1.96 & Excepted \\
\hline $\mathrm{H}_{17}$ & SI-SV & .43 .00 & 6.65 & 1.96 & Excepted \\
\hline $\mathrm{H}_{18}$ & SV-CVLW & 98.70 & 9.20 & 1.96 & Excepted \\
\hline
\end{tabular}

The test of all of the hypotheses in this research can be as strong evidence that prove all of the 18 hypotheses were correct. This result proved that the research literature background was classified as eligible.

\subsection{Structural Model Analysis}

The test of t-Value shows that the research models were fit with all the data collected. The score of $t$-Value 76.231 , and it is greater than probability base value of $0.000 \leq 0.001$, which means that the research data were also qualified. 
Table 3. Hypotheses Tests, F-Test

\begin{tabular}{|c|c|c|c|c|c|c|c|}
\hline \multicolumn{8}{|c|}{ Coefficient } \\
\hline Model & \multicolumn{2}{|c|}{ Un.Coeff. } & $\begin{array}{l}\text { Stand. } \\
\text { Coeff. }\end{array}$ & & Sig. & \multicolumn{2}{|c|}{$\begin{array}{l}\text { Collinearity } \\
\text { Statistics }\end{array}$} \\
\hline Const. & 0.89 & 5.7 & \multirow[b]{2}{*}{.005 } & .893 & .851 & Tol. & VIF \\
\hline PE & .005 & .083 & & .070 & .980 & 0.00 & 1.00 \\
\hline CVLW & 1.000 & & .852 & 76.231 & .000 & 0,000 & \\
\hline
\end{tabular}

The table 3 shows that there is no multi-collinearity correlation between overall research variables, with the value of $\mathrm{VIF}=1.00$.

Table 4. Model Fit-Test

\begin{tabular}{|c|c|c|c|}
\hline $\begin{array}{c}\text { Goodness of Fit } \\
\text { Index }\end{array}$ & $\begin{array}{c}\text { Cut-off } \\
\text { Value }\end{array}$ & $\begin{array}{c}\text { Model } \\
\text { Result }\end{array}$ & Category \\
\hline GFI & $\geq 0.9$ & 0.95 & Good Fit \\
\hline RMSEA & $\geq 0.9$ & 0.92 & Good Fit \\
\hline NFI & $\geq 0.9$ & 0.97 & Good Fit \\
\hline IFI & $0.8 \leq \mathrm{IFI} \leq 0.9$ & 0.88 & Marginal Fit \\
\hline CFI & $\geq 0.9$ & 0.96 & Good Fit \\
\hline RFI & $\geq 0.9$ & 0.98 & Good Fit \\
\hline
\end{tabular}

The table 4 shows that the research models were classified as Good Fit. At this point of result, can be concluded that the research model were based on valid and in-depth relevant theoretical analysis.

\subsection{Discussion of Implication}

In order to have better e-Government implementation, the governments should show their commitment (vision and mission) which is approved by the competent authorities; improve the skill of their human resources; create system documentations, standard operating procedures, or guidelines for managing electronic information, develop organizational culture, and have good marketing skill strategy during e-Government implementation.

This study is also expected to further identify the inhibiting factors of e-Government service innovation in developing countries. Our government should consider these factors to ensure the success of the e-Government service value to decrase the level of the poor.

\section{Conclusion}

Our research output produces some important conclusions as consideration in the implementation of eGovernment, particularly in the East Java province government. Leadership, human resources, information management, and cultural organizations were considered as inhibiting factors of e-Government implementation in East Java province government, where the service innovation in service value contributing most to improve the standard way of living. Thus, it is important for the governments in Indonesia to show their commitment and support for the success of the e-Government implementation. This study also concluded that the availability of IT infrastructure does not significantly inhibit the e-Government implementation in the 
East-Java province government. Finally, this research provides a trigger for the Indonesian government both central and local governments to develop and implement better e-government since e-government had been awaited by about 45 million Indonesian Internet users. Although the global ranking of e-Government readiness is in low level, but expectations of Internet users toward e-Government is very big.

\section{References}

Accenture (2014) Digital Government: Pathaway to Delivering Public Services for the Future, A Comparative Study of Digital Government Performance across 10 Countries, January, Available from: http://www.accenture/egovernment/indonesia advantages/service marketing/ service innovation/index.html.

Berry, L., Shankar, V., Parish, J., Cadwallader, S. and Dotzel, T. (2006) 'Creating new markets through service innovation', MIT Sloan Management Review, Vol. 47, No. 2, pp.56-63.

Bretschneider, S. (2003) 'Information technology, e-government, and institutional change', Public Administration Review, Vol. 63, No. 6, pp.738-741.

Brown, D. (2005) 'Electronic government and public administration', International Review of Administrative Science, Vol. 71, No. 2, pp.241-254.

Coursey, D. and Norris, D.F. (2008) 'Models of e-government: are they correct? An empirical assessment', Public Administration Review, Vol. 68, No. 3, pp.523-536.

Gilding, M. and Critchley, C. (2003) Technology and Trust: Public Perceptions of Technological Change in Australia. Australian Journal of Emerging Technologies and Society, 1, 1-17.

Hair, J.F., Black, W.C., Babin, B.J., Anderson, R.E., and Tatham, R.L., (2006),”Multivariate Data Analysis”, Pearson Prentice Hall, Upper Saddle River, New Jersey.

Hipp, C. and Grupp, H. (2005) 'Innovation in the service sector: the demand for service-specific innovation measurement concepts and typologies', Research Policy, Vol. 34, No. 4, pp.517-535.

Johnson, C. L. (2003) Financing and Pricing E-Service. In: Abramson, M. A. and Morin, T. L. E-government 2003, Rowman \& Littlefield Publishers Inc., USA.

Joines, J. L., Scherer, C. W. and Scheufele, D. A. (2003) Exploring motivations for consumer Web use and their implications for e-commerce. Journal of Consumer Marketing, 20, 90-108.

Lin, C. C. (2003) A Critical Appraisal of Customer Satisfaction and E-commerce. Marketing Audit Journal, 18, 202-212.

Norris, D. and Moon, M.J. (2005) 'Advancing e-government at the grassroots: tortoise or hare?' Public Administration Review, Vol. 65, No. 1, pp.64-75.

Ross, J., C. Beath, et al. (1996). "Develop long-term competitiveness through IT assets." Sloan Management Review, 38(1): 31-45.

Sundbo, J. (2008) 'Customer-based innovation of e-knowledge services: the importance of after-innovation', International Journal of Services Technology and Management, Vol. 9, No. 3/4, pp.218-233.

Taylor, S., \& Todd, P. (2005). Understanding information technology usage: A test of competing models. Information Systems Research, 6(2), 144-176.

The World Bank Group (2001) "How E-Government Interacts with Its Citizens", http://www.worldbank.org/html/prddr/trans/nfebmar03/pgs39-41.htm

West, D. (2005) 'E-government and the transformation of service delivery and citizen attitudes', Public Administration Review, Vol. 64, No. 1, pp.15-27.

United Nations (2005) "Global E-Government Readiness Report 2005: from E-Government to E-Inclusion", http://unpan1.un.org/intradoc/groups/public/documents/un/unpan02188.pdf

United Nations (2008) "UN E-Government Survey 2008: From E-Government to Connected Governance", http://unpan1.un.org/intradoc/groups/public/documents/UN/UNPAN02867.pdf

United Nations (2010) "UN E-Government Survey 2010: Leveraging E-Government at a Time of Financial and Economic Crisis", http://unpan1.un.org/intradoc/groups/public/UNPAN03885.pdf 